\title{
Superoxide Dismutase, Peroxidatic Activity and Catalase in Mycobacterium leprae Purified from Armadillo Liver
}

\author{
By P. R. WHEELER* AND D. GREGORY \\ National Institute for Medical Research, Mill Hill, London NW7 1 AA
}

(Received 25 March 1980; revised 15 May 1980)

\begin{abstract}
Superoxide dismutase has been identified and peroxidatic activity demonstrated in Mycobacterium leprae. The superoxide dismutase, shown indirectly to be a manganesecontaining enzyme, was present at low activity in the cell-free extract. Peroxidatic activity was detected in a haemoprotein on polyacrylamide gels, but quantitative assay was not possible. Catalase, although present in a cell-free extract, appeared to be a host-derived enzyme, thus emphasizing the importance of establishing the authenticity of enzyme activities in host-derived $M$. leprae. The implications for the growth of $M$. leprae in vivo and its non-cultivability are discussed in the light of these findings.
\end{abstract}

\section{INTRODUCTION}

Until recently, very little material for biochemical study of Mycobacterium leprae has been available. However, it is now possible to prepare about $50 \mathrm{mg}$ (dry wt) of pure bacteria from $50 \mathrm{~g}$ (wet wt) of liver from experimentally infected armadillos, representing an increase of 2 to 3 orders of magnitude over the yield from human biopsy.

Initially, it was decided to study superoxide dismutase (EC 1.15.1.1; superoxide: superoxide oxidoreductase), catalase (EC 1.11.1.6; hydrogen-peroxide:hydrogenperoxide oxidoreductase) and peroxidase (EC 1.11.1.7; donor:hydrogen-peroxide oxidoreductase) since these enzymes may play a role in the survival of $M$. leprae inside host phagocytes, which produce superoxide radical $\left(\mathrm{O}_{2}^{-}\right)$and $\mathrm{H}_{2} \mathrm{O}_{2}$ (Karnovsky et al., 1975; Segal $\&$ Allison, 1979). Superoxide dismutase has been observed in all mycobacteria so far studied (Kusunose et al., 1976a, b; Ichihara et al., 1977); this enzyme appears to be a pre-requisite for aerobiosis (Fridovich, 1975). Catalase and peroxidase are present in most mycobacteria (Tirunarayanan \& Vischer, 1957), but are notably absent in isoniazid-resistant strains of M. tuberculosis. Catalase-negative strains were found to be more susceptible to $\mathrm{H}_{2} \mathrm{O}_{2}$ and this was one of the factors associated with low virulence (Jackett et al., 1978). Wayne \& Diaz $(1976,1979)$ have used mycobacterial catalases in taxonomic studies.

Since bacteria were harvested from host tissue, it was important to establish that enzyme activities in the cell-free extracts of $M$. leprae were, in fact, due to bacterial enzymes. A rigorous scheme of purification of the bacteria was followed before certain properties of the enzymes, particularly electrophoretic mobility, were compared with similar enzymes from a cell-free extract of armadillo liver.

Mycobacteria other than $M$. leprae were used for comparison and also for establishing suitable methods without using valuable $M$. leprae cell-free extract.

\section{METHODS}

Organisms used. Mycobacterium leprae was obtained from heavily [ $>5 \times 10^{9}$ bacilli (g wet wt tissue $\left.)^{-1}\right]$ infected liver (either fresh or stored at $-80^{\circ} \mathrm{C}$ ) of experimentally infected nine-banded armadillos (Dasypus 
novemcinctus, Linn.) by the methods described in 'Report' (1979). The infected liver was homogenized in Tris base and centrifuged. The fraction rich in bacteria was then treated with DNAase (DNAase 1, Worthington Biochemical Corporation) followed by density gradient centrifugation using Percoll (Pharmacia), and partitioning in a dextran/polyethylene glycol aqueous two-phase system. The upper phase was then centrifuged and the pellet, which consisted of $M$. leprae, was washed. The bacteria obtained were free of contaminating tissue, as judged by counterstaining with soluble blue (Wheeler \& Draper, 1980).

A sample of pute $M$. leprae $\left(10 \mathrm{mg}\right.$ dry wt) was treated with $5 \mathrm{ml} 1 \mathrm{M}-\mathrm{NaOH}$ at $25^{\circ} \mathrm{C}$. The suspension was neutralized after $1 \mathrm{~h}$ with $1 \mathrm{M}$-citric acid and centrifuged at $10000 \mathrm{~g}$ for $10 \mathrm{~min}$. The pellet was washed three times and resuspended in $1.5 \mathrm{mM}-N$-2-hydroxyethylpiperazine- $N^{\prime}$-2-ethanesulphonic acid (HEPES; adjusted to $\mathrm{pH} 7 \cdot 2$ with $\mathrm{KOH}$ ). The supernatant was desalted and concentrated to $2 \mathrm{ml}$ using an Amicon CF25 centrifuge ultrafiltration cone $\left(700 \mathrm{~g}, 4^{\circ} \mathrm{C}\right)$; the final concentration of citrate was calculated to be $10 \mathrm{~mm}$.

Mycobacterium lepraemurium was grown in mice and harvested from liver (Rees et al., 1960). Bacteria were obtained free from contamination by differential centrifugation and partition in an aqueous two-phase system [5\%(w/w) polyethylene glycol (PEG) 6000/7\% (w/w) Dextran T500/0.01 M-NaCl/0.01 M-potassium phosphate, pH 6.9]. Mycobact rrium phlei NCTC 10266 was grown in Headley-Wright nutrient broth with $0.05 \%(\mathrm{v} / \mathrm{v})$ Tween 80 at $37^{\circ} \mathrm{C}$.

Preparation of bacterial cell-free extracts. Bacteria (10 to $60 \mathrm{mg}$ dry wt) were suspended in a total volume of $10 \mathrm{ml} 1.5 \mathrm{~mm}$-HEPES (adjusted to $\mathrm{pH} 7.2$ with $\mathrm{KOH}$ ) and ultrasonically treated for periods no longer than $3 \mathrm{~min}$ for a total of $15 \mathrm{~min}$ for $M$. phlei and $M$. lepraemurium and $11 \mathrm{~min}$ for $M$. leprae at $100 \mathrm{~W}$ in a Dawe Soniprobe type 7532A, cooled on wet ice. The probe was completely enclosed in a Dawe SealedAtmosphere Treatment Chamber type 7530-5A in order to contain the aerosol formed. The disrupted material was centrifuged at $20000 \mathrm{~g}$ for $10 \mathrm{~min}$ and the supernatant was re-centrifuged for $10 \mathrm{~min}$ to remove remaining bacteria and debris. The final supernatant (cell-free extract), containing 0.25 to $1.5 \mathrm{mg}$ protein $\mathrm{ml}^{-1}$ was stored at $-80^{\circ} \mathrm{C}$. It was not possible to detect acid-fast bacteria in a pellet (obtained by centrifuging at $20000 \mathrm{~g}$ for $10 \mathrm{~min}$ ) from the cell-free extract.

Preparation of cell-free extract of armadillo liver. A slight modification of the early stages of purification of manganese-superoxide dismutase from liver (Crapo et al., 1978) was used. Liver from an armadillo which had been inoculated, but had not become infected, was used. The liver was suspended at $4^{\circ} \mathrm{C}$ in 3.5 vol. buffer containing 20 mM-HEPES (adjusted to pH 7.8 with $\mathrm{KOH}$ ) plus $10 \mu \mathrm{M}$-EDTA, and homogenized for $3 \times 2 \mathrm{~min}$ in a Sorvall Omnimix. Debris was removed by centrifugation at $14000 \mathrm{~g}$ for $30 \mathrm{~min}$. The supernatant material was dialysed against distilled water for $24 \mathrm{~h}$, lyophilized and then dissolved in distilled water to at least $10 \mathrm{mg}$ protein $\mathrm{ml}^{-1}$ when required. Liver extract, either lyophilized or in solution, was stored at $-20^{\circ} \mathrm{C}$.

Enzyme assays. Superoxide dismutase was assayed indirectly by following the inhibition of the reduction by $\mathrm{O}_{2}{ }^{-}$of nitroblue tetrazolium ('NBT assay' of Beauchamp \& Fridovich, 1971) or of ferricytochrome $c$ (Crapo et al., 1978), at $25^{\circ} \mathrm{C}$. These methods were modified so that the reaction volumes were $500 \mu l$, and $20 \mu \mathrm{M}-\mathrm{KCN}$ was included in all assays. It was necessary to remove superoxide dismutase-like activity present in the cytochrome $c$ (Koch-Light) by Sephadex G-75 chromatography and then to assay the cytochrome $c$ by reduction with sodium dithionite (Crapo et al., 1978) before it was used in the assay for superoxide dismutase.

Catalase was assayed by a modification of the method described by Winder (1960). The reaction mixture (total volume $150 \mu \mathrm{l}$ ) contained $10 \mathrm{~mm}-\mathrm{H}_{2} \mathrm{O}_{2}, 1.33 \mathrm{mg}$ bovine serum albumin $\mathrm{ml}^{-1}, 17 \mathrm{~mm}-\mathrm{NaH}_{2} \mathrm{PO}_{4} /$ $\mathrm{K}_{2} \mathrm{HPO}_{4}$, pH 7.0, cell-free extract and inhibitors. The mixture was incubated at $25^{\circ} \mathrm{C}$ and the reaction was stopped, usually after $30 \mathrm{~min}$, by adding $4.4 \mathrm{ml} \mathrm{TiCl}$ reagent $\left(0.33 \mathrm{mg} \mathrm{ml}^{-1}\right.$ in $\left.1.5 \mathrm{M}^{-\mathrm{H}_{2}} \mathrm{SO}_{4}\right)$.

Peroxidatic activity was assayed by the method of Putter (1974) except that $o$-dianisidine hydrochloride was used instead of guaiacol.

Polyacrylamide gel electrophoresis. Cylindrical $(70 \mathrm{~mm} \times 5 \mathrm{~mm}$ diam.) small pore gels including $N, N^{\prime}$-methylene bisacrylamide as $3 \%$ of the acrylamide (with no stacking gel) were used. Aqueous bromophenol blue was used as the tracking dye in each gel. Superoxide dismutase and peroxidatic activity were detected using the methods of Misra \& Fridovich (1977), except that $8 \%(\mathrm{w} / \mathrm{v}$, total acrylamide) gels were used. It was possible to stain for peroxidatic activity, wash the gels for 15 min in distilled water, then stain for superoxide dismutase (omitting cyanide), thus demonstrating superoxide dismutase-positive areas in the same gels. Cyanide was always used in gels stained for superoxide dismutase only. Mn- and Fesuperoxide dismutases were differentiated by the method of Britton et al. (1978).

The method for detecting catalase was based on that used by Diaz \& Wayne (1974) using $5 \%$ (w/v, total acrylamide) gels (Clarke, 1964). Initially, we used starch in our assay but this was subsequently replaced by a more satisfactory system employing a stain based on ferricyanide (Woodbury et al., 1971). 
Table 1. Comparison of superoxide dismutase from $M$. leprae extracts and other cell-free extracts

Percentage inhibition of NBT or cytochrome $c$ reduction was plotted against the concentration of protein (in cell-free extracts) and the specific activity in units (mg protein) ${ }^{-1}$ was calculated (Beauchamp \& Fridovich, 1971; Crapo et al., 1978). Since the incubation mixture was $500 \mu 1,50 \%$ inhibition was said to be caused by 0.167 units. Except for $M$. leprae an incubation was carried out in which about $50 \%$ inhibition actually occurred. Cell-free extracts were then applied to $8 \%(\mathrm{w} / \mathrm{v})$ polyacrylamide gels. Some bands were identified as Fe-superoxide dismutase by inhibition by $\mathrm{H}_{2} \mathrm{O}_{2}$. A slight difference in the specific activity of superoxide dismutase was noted for two preparations of $M$. leprae cell-free extracts; the values for both are given.

\begin{tabular}{|c|c|c|c|c|}
\hline \multirow[b]{2}{*}{ Cell-free extract } & \multicolumn{2}{|c|}{$\begin{array}{c}\text { Superoxide dismutase specific activity } \\
\left.\text { [urits (mg protein })^{-1}\right]\end{array}$} & \multirow{2}{*}{$\begin{array}{l}\text { Relative } \\
\text { mobility }\end{array}$} & \multirow{2}{*}{$\begin{array}{c}\text { Bands inhibited } \\
\text { by } \mathrm{H}_{2} \mathrm{O}_{2}\end{array}$} \\
\hline & NBT assay & Cyt $c$ assay & & \\
\hline M. leprae 1 & $\begin{array}{l}0.043 \\
0.075\end{array}$ & $\left.\begin{array}{c}\text { ND } \\
0.17\end{array}\right\}$ & $0 \cdot 68$ & None \\
\hline M. lepraemurium & $7 \cdot 7$ & $14 \cdot 3$ & $0 \cdot 36$ & None \\
\hline M. phlei & $7 \cdot 8$ & $5 \cdot 9$ & $0 \cdot 34,0 \cdot 78$ & $0 \cdot 78$ \\
\hline Armadillo liver & $16 \cdot 6$ & $9 \cdot 3$ & $0.27,0.50$ & 0.50 \\
\hline
\end{tabular}

ND, Not determined.

\section{RESULTS}

Superoxide dismutase

The activity of superoxide dismutase in extracts from $M$. leprae was low in comparison with that in extracts from other mycobacteria (Table 1). The assay involving cytochrome $c$ was more sensitive than the NBT assay for $M$. leprae and $M$. lepraemurium, but the NBT assay was more sensitive for armadillo liver and $M$. phlei superoxide dismutases.

It was important to include $20 \mu \mathrm{M}-\mathrm{KCN}$ in this assay to prevent interference by peroxidative reactions, which also inhibited reduction of NBT and cytochrome $c$, resulting in higher apparent specific activities of superoxide dismutase. For instance, a $2 \cdot 4$-fold overestimation with the NBT assay and a 1.7-fold overestimation with the cytochrome $c$ assay occurred for $M$. lepraemurium cell-free extract. With $M$. leprae cell-free extract, a $2 \cdot 2$-fold overestimate occurred using the NBT assay if cyanide was omitted. However, if the KCN concentration was increased up to $2 \mathrm{mM}$, there was no further inhibition of cytochrome $c$ or NBT reduction in the presence of any of the cell-free extracts tested.

It is unlikely that the method of isolation of pure $M$. leprae affected superoxide dismutase activity, since the cell-free extract of $M$. phlei suspension which had been exposed to the same purification procedure had a specific activity [ 7.6 units (mg protein $)^{-1}$ ] not significantly different from that of an extract of $M$. phlei suspension which had simply been washed free of incubation medium. Polyacrylamide gel electrophoresis followed by staining for superoxide dismutase showed a single band for $M$. leprae cell-free extract, in a different position from the two armadillo liver superoxide dismutase bands (Table 1). Well-defined bands could be obtained with $200 \mu \mathrm{g}$ liver protein and $600 \mu \mathrm{g} M$. leprae protein. It was possible to include liver and $M$. leprae cell-free extracts on the same gel and show the three superoxide dismutase bands exhibiting the expected mobilities.

\section{Catalase}

Catalase was detected in $M$. leprae cell-free extracts, but this catalase could not be distinguished from armadillo liver catalase (Table 2). Pre-incubation of extracts for $20 \mathrm{~min}$ at $25^{\circ} \mathrm{C}$ with 3 -amino-1,2,4-triazole (at $1.5 \times$ concentrations in Table 2) followed by addition of $\mathrm{H}_{2} \mathrm{O}_{2}$ and incubation for $30 \mathrm{~min}$ failed to demonstrate any differences in inhibition between $M$. leprae and armadillo liver enzyme activity $(M$. phlei catalase appeared 
Table 2. Comparison of catalase from $M$. leprae extracts and other cell-free extracts

The assay is described in Methods. One unit of catalase activity is defined as $(1 / t) \times \ln \left(S_{0} / S_{\mathrm{t}}\right)$, where $t$ is the incubation time (s); and $S_{0}$ and $S_{\mathrm{t}}$ are the concentrations of $\mathrm{H}_{2} \mathrm{O}_{2}$ at zero time and at the end of the incubation, respectively (Winder, 1960). For inhibition studies, $1.4 \times 10^{-4}$ units catalase was pre-incubated for $20 \mathrm{~min}$ with 3-amino-1,2,4-triazole before $\mathrm{H}_{2} \mathrm{O}_{2}$ was added. The reaction was stopped after $30 \mathrm{~min}$. Cell-free extracts were applied to $5 \%(\mathrm{w} / \mathrm{v})$ polyacrylamide gels.

\begin{tabular}{|c|c|c|c|c|c|}
\hline \multirow[b]{2}{*}{ Cell-free extract } & \multirow{2}{*}{$\begin{array}{c}10^{3} \times \text { Catalase } \\
\text { specific activity } \\
{\left[\text { units }(\mathrm{mg} \text { protein })^{-1}\right]}\end{array}$} & \multicolumn{3}{|c|}{$\begin{array}{c}\text { Inhibition }(\%) \text { by } \\
\text { 3-amino-1,2,4-triazole }\end{array}$} & \multirow[b]{2}{*}{ Relative mobility } \\
\hline & & $1 \mathrm{~mm}$ & $10 \mathrm{~mm}$ & $100 \mathrm{~mm}$ & \\
\hline M. leprae & $1 \cdot 35 \pm 0 \cdot 30^{*}$ & 46 & 81 & 100 & $0 \cdot 27$ \\
\hline Armadillo liver & 400 & 47 & 79 & 98 & 0.27 \\
\hline M. phlei & $10 \cdot 6 \pm 3 \cdot 1^{*}$ & 51 & 69 & 90 & $0.77,0.86$ \\
\hline M. lepraemurium & $8 \cdot 4$ & ND & ND & ND & $0 \cdot 70,0.75$ \\
\hline
\end{tabular}

ND, Not determined.

* \pm Standard error, four separate extracts.
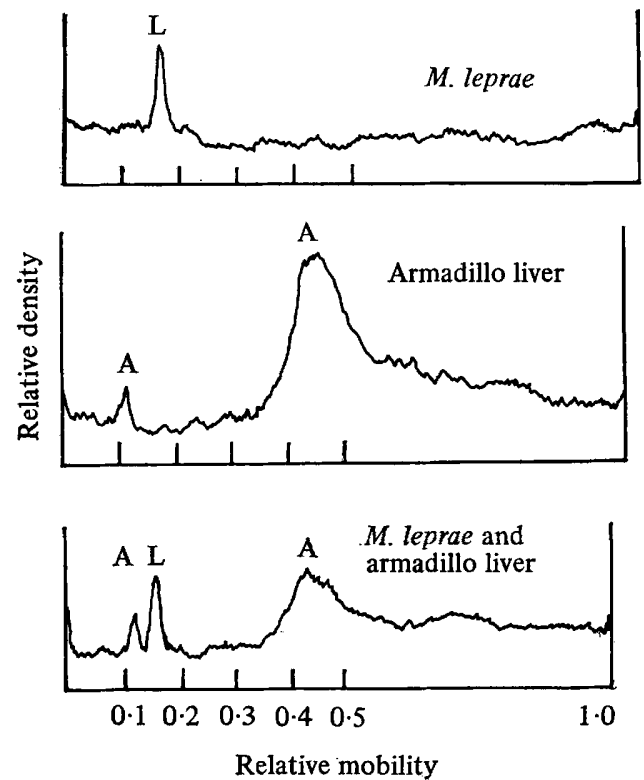

Fig. 1. Peroxidatic activity in $M$. leprae extracts and in cell-free extract of armadillo liver. Polyacrylamide gels loaded with $M$. leprae and armadillo liver extract, run both separately and combined, were stained for peroxidatic activity and scanned by transmitted light (slit width $0.06 \mathrm{~mm}$ ) on a Joyce Loebl microdensitometer Mk III: A, bands from cell-free extract of armadillo liver; $\mathrm{L}$, bands from $M$. leprae extract. No bands were observed if $\mathrm{H}_{2} \mathrm{O}_{2}$ was omitted from the staining procedure.

to be slightly less susceptible to higher concentrations of 3-amino-1,2,4-triazole). After polyacrylamide gel electrophoresis, only a single band of catalase activity was detected for both liver ( $3.2 \mu \mathrm{g}$ protein) and $M$. leprae (100 $\mu \mathrm{g}$ protein) extracts, both with a relative mobility of $0 \cdot 27$. This could not be resolved into further bands by increasing the $M$. leprae cell-free extract protein applied to the gel up to $1 \mathrm{mg}$, or by combining $M$. leprae and liver cell-free extracts on the same gel. The relative mobility was different from that of bands from other mycobacteria: $M$. phlei, M. lepraemurium (Table 2) and M. tuberculosis (Diaz \& Wayne, 1974) bands with catalase activity all had relative mobilities of $0 \cdot 70$ to $0 \cdot 86$. 


\section{Peroxidatic activity}

Attempts to assay peroxidatic activity in $M$. leprae cell-free extracts to estimate specific activity were unsuccessful, but peroxidatic activity could be demonstrated on a polyacrylamide gel (Fig. 1). In a gel loaded with $M$. leprae cell-free extract containing $750 \mu \mathrm{g}$ protein, a thin, brown band was observed after electrophoresis; after staining $\left(\mathrm{H}_{2} \mathrm{O}_{2}\right.$ followed by $o$-dianisidine) as described in Methods, a very thin orange band was observed in the same place. The stained gel could be stored in distilled water for several weeks at room temperature without loss of intensity or diffusion of the stained band, since the oxidized $o$-dianisidine product is highly insoluble in water. The unstained coloured protein would have diffused during such storage. The band of peroxidatic activity did not stain in a control in which $\mathrm{H}_{2} \mathrm{O}_{2}$ was omitted. A band with similar properties (before and after staining) was observed for liver cell-free extract, but this was shown to be a different protein by running liver extract ( $400 \mu \mathrm{g}$ protein) and $M$. leprae cell-free extract ( $700 \mu \mathrm{g}$ protein) on the same gel. Two bands, before and after staining, were observed in the same positions where they had been observed when run separately (Fig. 1). An additional band of peroxidatic activity, more intense and diffuse, was detected from liver extracts.

Gels stained for peroxidatic activity could be washed for $15 \mathrm{~min}$ in distilled water immediately after the bands corresponding to peroxidatic activity had developed, then stained for superoxide dismutase. Bands with the characteristic mobilities (Table 1) of liver and $M$. leprae superoxide dismutases were observed (as well as the bands of peroxidatic activity) on such gels.

\section{Effect of $\mathrm{NaOH}$ treatment on enzyme activities}

It was possible to detect catalase in suspensions of whole $M$. leprae. By calculating the protein equivalent (protein obtained in the cell-free extract from the bacteria), it could be shown that the specific activity was $1 \cdot 1 \times 10^{-3}$ units (mg protein equivalent) ${ }^{-1}$, a value in the range of specific activities of extracts (Table 2 ). This activity was inhibited completely by $100 \mathrm{~mm}$-3-amino-1,2,4-triazole. Treatment with $\mathrm{NaOH}$, as described in Methods, completely abolished any catalase activity that could be detected in whole bacteria. Very little protein ( $25 \mu \mathrm{g}$ from $10 \mathrm{mg}$ bacteria) and no catalase activity was released by the $\mathrm{NaOH}$ treatment.

The cell-free extract prepared from $\mathrm{NaOH}$-treated $M$. leprae contained no catalase activity [the minimum specific activity that could be detected was $10^{-5}$ units (mg protein $)^{-1}$ ] and 0.050 units superoxide dismutase (mg protein) ${ }^{-1}$ using the NBT assay. Peroxidatic activity and superoxide dismutase from the $\mathrm{NaOH}$-treated bacteria could both be detected on polyacrylamide gels.

\section{DISCUSSION}

The results obtained for catalase activity emphasize the importance of establishing that any enzyme activity detected in cell-free extracts or in cell suspensions of tissue-grown bacteria is, in fact, a bacterial enzyme. It was not possible, either by investigation of the pattern of inhibition by 3-amino-1,2,4-triazole or by polyacrylamide gel electrophoresis (even with heavy loading of the bacterial cell-free extract), to show any difference between the host liver and the ' $M$. leprae' enzymes. There was no evidence for the existence of an $M$. leprae catalase. On the contrary, the evidence suggested that the enzyme found in the $M$. leprae cell-free extract was, in fact, armadillo liver catalase; its electrophoretic mobility contrasted sharply with those of all other mycobacterial catalases on $5 \%$ polyacrylamide gels (results presented here, and by Diaz \& Wayne, 1974).

Authentic $M$. leprae superoxide dismutase and peroxidatic activity were, however, detected. Neither of the corresponding enzymes from the liver were present in $M$. leprae 
cell-free extracts. $\mathrm{NaOH}$ treatment has been shown to abolish acid phosphatase activity attached superficially to the surface of M. tuberculosis (Kanai, 1967). Such treatment of a suspension of pure $M$. leprae (which does not affect its viability; C. Lowe, unpublished results) abolished catalase activity, while superoxide dismutase and peroxidatic activity were unaffected. These results are further evidence for $M$. leprae superoxide dismutase and peroxidatic activity being of bacterial origin and for catalase being host-originated. Kanai (1967) has suggested that tubercule bacilli become coated with host-material as they become established in host tissues and this may be seen as an adaptation to intracellular growth. Mycobacterium leprae may similarly become coated with host-material during its growth in the liver, and this would account for the presence of catalase. However, we cannot exclude that the host-material is adsorbed on to the surface of the leprosy bacteria during isolation.

Peroxidatic activity could only be detected on polyacrylamide gels, possibly because it was concentrated into a sharp band. In the absence of such concentration, the assay described by Putter (1974) was probably not sensitive enough to detect peroxidatic activity in extracts of $M$. leprae. The peroxidatic nature of this band was confirmed by omitting $\mathrm{H}_{2} \mathrm{O}_{2}$ from the stain, when no colour developed. A single band, which was brown prior to staining, was observed suggesting that it was a haemoprotein. It was not clear whether this represented a true peroxidase: for instance, non-specific peroxidatic activity of a respiratory pigment may have been observed.

Mycobacterium leprae superoxide dismutase activity was not inhibited by pre-incubation in $5 \mathrm{~mm}-\mathrm{H}_{2} \mathrm{O}_{2}$ (Britton et al., 1978) or by assaying with $2 \mathrm{~mm}-\mathrm{KCN}$ (Crapo et al., 1978). These results are consistent with it being a manganese-containing enzyme. Such an enzyme has been purified from M. lepraemurium (Ichihara et al., 1977). We have further shown in this paper that $M$. leprae and $M$. lepraemurium both possess a superoxide dismutase more easily detected at $\mathrm{pH} 7 \cdot 8$ than $\mathrm{pH} 10$. Generally, the reverse is true (Crapo et al., 1978). This suggests that for these mycobacterial enzymes the ratio of rate constants for $\mathrm{O}_{2}{ }^{-}$at $\mathrm{pH} 10$ compared with that at $\mathrm{pH} 7.8$ are rather lower (Klug et al., 1972) than for other superoxide dismutases. The cell-free extract from which Ichihara et al. (1977) prepared superoxide dismutase had a specific activity 13 times higher than the extract which we prepared from whole $M$. lepraemurium (grown in vivo) by a method similar to that used by Ichihara et al. (1977). The difference in specific activities may reflect a difference between the organism grown in culture medium and in mice. Using the NBT assay, the specific activity of $M$. leprae superoxide dismutase was less than $1 \%$ of the specific activity in other mycobacterial cell-free extracts (and also cell-free extract from armadillo liver).

The specific activity of superoxide dismutase is proportionately lower than certain hydrolytic enzymes (acid phosphatase, some glycosidases), where the specific activity in $M$. leprae cell-free extracts is about $5 \%$ of the specific activity in cell-free extracts from other mycobacteria ( $M$. phlei, M. lepraemurium; unpublished results). In view of the importance of superoxide dismutase (Gregory \& Fridovich, 1973) and catalase (Gifford, 1968 ) in the survival and growth of bacteria, the low activity of superoxide dismutase and absence of catalase might be one of the reasons for the slow growth of $M$. leprae in vivo.

It has been shown that peroxides form in bacteriological media (Barry et al., 1956). If $M$. leprae cannot produce catalase and has low superoxide dismutase and peroxidatic activities, the effect of toxic anions in media may contribute to the failure of the organism to grow in such conditions.

The method of preparation of pure bacteria (at least when carried out using $M$. phlei) does not affect the superoxide dismutase activity so it seems unlikely that loss of activity during purification was a reason for low activity of superoxide dismutase. Generally, the specific activities of enzymes in $M$. leprae might be expected to be low since only a small proportion (about $10 \%$ ) of the bacteria are viable (McDougall et al., 1979).

It has been suggested (Jackett et al., 1978) that unsaturated lipids in the lipid-rich cell-wall 
of $M$. tuberculosis might act as a defence against $\mathrm{H}_{2} \mathrm{O}_{2}$ and $\mathrm{O}_{2}^{-}$by offering a substrate for harmless lipoperoxidation. Such cell-wall lipids might offer some protection in $M$. leprae where the enzymological defence against toxic anions appears to be incomplete.

We wish to thank Dr R. J. W. Rees and Dr P. Draper for invaluable discussion and help in the preparation of this manuscript, and $\mathrm{Mr} \mathrm{A}$. Harris for assistance with the microdensitometry. LEPRA (British Leprosy Relief Association) provided funds for maintaining the colony of infected armadillos.

\section{REFERENCES}

Barry, V. C., Conalty, M. L., Denneny, J. M. \& WINDER, F. (1956). Peroxide formation in bacteriological media. Nature, London 178, 596-597.

Beauchamp, C. \& Fridovich, I. (1971). Superoxide dismutase: improved assays and an assay applicable to acrylamide gels. Analytical Biochemistry 44, 276-287.

Britton, L., Malinowski, D. P. \& Fridovich, I. (1978). Superoxide dismutase and oxygen metabolism in Streptococcus faecalis. Journal of Bacteriology 134, 229-236.

Clarke, J. T. (1964). Simplified 'disc' (polyacrylamide gel) electrophoresis. Annals of the New York Academy of Sciences 121, 428-436.

Crapo, J. D., McCord, J. M. \& Fridovich, I. (1978). Preparation and assay of superoxide dismutases. Methods in Enzymology 53, 382393.

DiAZ, G. A. \& WAYNE, L. G. (1974). Isolation and characterization of catalase produced by $\mathrm{Myco}$ bacterium tuberculosis. American Review of Respiratory Disease 110, 312-319.

Fridovich, I. (1975). Superoxide dismutases. Annual Review of Biochemistry 44, 147-159.

GIFFORD, G. D. (1968). Toxicity of hyperbaric oxygen to bacteria in relation to cell cycle and catalase synthesis. Journal of General Microbiology 52, 375-379.

Gregory, E. M. \& Fridgvich, I. (1973). Oxygen toxicity and the superoxide dismutase. Journal of Bacteriology 114, 1193-1197.

IChihara, K., Kusunose, E., Kusunose, M. \& Mori, T. (1977). Superoxide dismutase from Mycobacterium lepraemurium. Journal of Biochemistry 81, 1427-1433.

JACKetT, P. S., Aber, V. R. \& Lowrie, D. B. (1978). Virulence and resistance to superoxide, low $\mathrm{pH}$, and hydrogen peroxide among strains of $\mathrm{Myco}$ bacterium tuberculosis. Journal of General Microbiology 104, 37-45.

KanaI, K. (1967). Detection of host originated acid phosphatase on the surface of in vivo grown tubercule bacilli. Japanese Journal of Medical Science and Biology 20, 73-90.

Karnovsky, M. L., Lazdins, J., Drath, D. \& HARPER, A. (1975). Biochemical characteristics of activated macrophages. Annals of the New York Acadomy of Sciences 256, 266-274.

Klug, D., Rabani, J. \& Fridovich, I. (1972). A direct demonstration of the catalytic action of superoxide dismutase through the use of pulse radiolysis. Journal of Biological Chemistry 247, 4839-4842.

Kusunose, E., Noda, Y., Ichihara, K. \& Kusunose, M. (1976a). Superoxide disnutase from Mycobacterium species, strain Takeo. Archives of Microbiology 108, 65-73.

Kusunose, E., Ichihara, K., Noda, Y. \& Kusunose, M. (1976b). Superoxide dismutase from Mycobacterium tuberculosis. Journal of Biochemistry 80, 1343-1352.

MCDougall, A. C., Rees, R. J. W. \& Lowe, C. (1979). The histopathology of experimental leprosy in the armadillo: Dasypus novemcinctus, Linn., and Dasypus sabanicola, Linn. International Journal of Leprosy 47, 343 (abstract).

MisRa, H. P. \& Fridovich, I. (1977). Superoxide dismutase and peroxidase: a positive activity stain applicable to polyacrylamide gel electrophorograms. Archives of Biochemistry and Biophysics 183, 511-515.

PutTER, J. (1974). Peroxidases. In Methods of Enzymatic Analysis, 2nd English edn, pp. 685-690. Edited by H.-U. Bergmeyer. London: Academic Press.

Rees, R. J. W., Valentine, R. C. \& Wong, P. C. (1960). Application of quantitative electron microscopy to the study of Mycobacterium lepraemurium and $M$. leprae. Journal of General Microbiology 22, 443-457.

REPORT (1979). Problems related to purification of $M$. leprae from armadillo tissues and standardization of $M$. leprae preparations. Report on the Enlarged Steering Committee Meeting, Geneva, 7-8 February, 1979. WHO Document TDR/ $I M M L E P$.

Segal, A. W. \& Allison, A. C. (1979). Oxygen consumption by stimulated human neutrophils. CIBA Foundation Symposia 65, 205-224.

Tirunarayanan, M. O. \& Vischer, W. A. (1957). Catalase, peroxidase and isoniazid relation in mycobacteria. American Review of Tuberculosis 75, 62-70.

Wayne, L. G. \& Diaz, G. A. (1976). Immunoprecipitation studies of mycobacterial catalase. International Journal of Systematic Bacteriology 26, 38-44.

Wayne, L. G. \& Diaz, G. A. (1979). Reciprocal immunological distances of catalase derived from strains of Mycobacterium avium, Mycobacterium tuberculosis, and closely related species. International Journal of Systematic Bacteriology 29, 19-24. 
Wheeler, P. R. \& Draper, P. (1980). Soluble blue as a counterstain in the Ziehl-Neelsen procedure. International Journal of Leprosy 48, 15-17.

Winder, F. (1960). Catalase and peroxidase in mycobacteria: possible relationship to the mode of action of isoniazid. American Review of Respiratory Disease 81, 68-78.
Woodbury, W., Spencer, A. K. \& StahmanN, M. A. (1971). An improved procedure using ferricyanide for detecting catalase enzymes. Analytical Biochemistry 44, 301-305. 